\title{
URGENSI ZAKAT, INFAK, DAN SEDEKAH DI MASA PENDEMI COVID-19 PRESPEKTIF MAQASID SYARIAH
}

\author{
Jefik Zulfikar Hafizd dan Ditta Mardiatta \\ Institut Agama Islam Negeri Syekh Nurjati Cirebon \\ Email: jefikzulfikarhafizd@syekhnurjati.ac.id dan mardiatta20@gmail.com
}

\begin{abstract}
The contribution of the Amil Zakat Institution is needed to deal with economic problems caused by the Covid-19 pandemic. Zakat, Infaq, Alms (ZIS) play an important role for Muslims both in terms of worship and economic development. Through this literature study, it examines the urgency of ZIS according to the perspective of Maqasid Syariah and how the efforts of BAZNAS Cirebon City in dealing with the impact of the pandemic on the economy. The results show that the existence of ZIS during the Covid-19 Pandemic is in accordance with four of the five values of Maqasid Syariah, namely to protect religion, soul, mind, and property. Various programs compiled by BAZNAS Cirebon City are in accordance with existing needs and do not conflict with Islamic law and positive law. BAZNAS Cirebon City implemented the BAZNAS MEMBUMI (Assisting Pandemic Impact) program with the Cirebon City government to provide an optimistic spirit to the community to be able to face the pandemic.
\end{abstract}

Keywords: ZIS, the Pandemic, and Maqasid Sharia.

\begin{abstract}
Abstrak
Kontribusi Lembaga Amil Zakat sangat diperlukan untuk menangani masalah ekonomi diakibatkan oleh pandemi Covid-19. Zakat, Infak, Sedekah (ZIS) memegang peranan penting bagi umat Islam baik dari sisi ibadah maupun pembangunan ekonomi. Melalui studi kepustakaan ini penulis mengkaji mengenai urgensi ZIS menurut perspektif Maqasid Syariah dan bagaimana upaya BAZNAS Kota Cirebon dalam menangani dampak pendemi terhadap ekonomi. Hasil penelitian menunjukkan bahwa adanya ZIS pada masa Pandemi Covid-19 sesuai dengan empat dari lima nilai Maqasid Syariah yaitu untuk menjaga agama, jiwa, akal, dan harta. Berbagai program yang disusun oleh BAZNAS Kota Cirebon sesuai dengan kebutuhan yang ada dan tidak bertentangan dengan hukum Islam dan hukum positif. BAZNAS Kota Cirebon melaksanakan program BAZNAS MEMBUMI (Membantu Dampak Pandemi) bersama pemerintah Kota Cirebon untuk memberikan semangat optimis kepada masyarakat untuk mampu menghadapi pandemi.
\end{abstract}

Kata Kunci: ZIS, Pendemi, dan Maqasid Syariah. 


\section{PENDAHULUAN}

Maqhasid Syariah dalam konteks ekonomi Islam, merupakan jantung dalam ilmu ushul fiqh, karena itu Maqhasid Syariah menduduki posisi yang sangat penting dalam merumuskan ekonomi Islam menciptakan produk-produk perbankan dan keuangan syariah. Sehingga Tujuan utama dari ekonomi islam adalah Maqasid alsyariahitu sendiri, yaitu tercapainya kebahagiaan di dunia dan akhirat (falah) melalui tatanan kehidupan yang baik dan terhormat. Itulah kesejahteraan hakiki yang untuk sampai padanya harus ada perlindungan terhadap keimanan, ilmu, kehidupan, keturuan, dan harta.

Akibatnya terjadinya penurunan aktivitas manusia, para pelaku usaha khususnya pedagang kecil terpaksa berhenti berjualan sehingga mereka tidak memiliki pemasukan. Pandemi COVID-19 menyebabkan dampak luar biasa kepada ekonomi sehingga bisa menyebabkan peningkatan jumlah kemiskinan jika tidak ditanggulangi (Hafizd, 2020). Hampir seluruh Negara di dunia termasuk Indonesia sedang dilanda musibah besar yaitu menyebarnya virus corona (Covid-19). Sehingga banyak masyarakat yang terkena imbas dari adanya wabah tersebut. Dari segi ekonomi, masyarakat kecil terkena efek dari pembatasan sosial demi mencegah penyebaran virus ini. Sebagian terpaksa harus terputus mata pencahariannya, terlebih lagi bagi yang sebelumnya memiliki kondisi ekonomi yang kurang mencukupi. Virus corona (Covid-19) yang terjadi di Indonesia mengalami trend kasus positif yang meningkat meski disisi lain terdapat pasien yang dinyatakan sembuh.

Mengantisipasi dan mengurangi jumlah penderita virus corona di Indonesia sudah dilakukan tindakan vaksinasi hampir di seluruh daerah termasuk Kabupaten dan Kota Cirebon ini. Selain itu juga dengan memberikan kebijakan membatasi aktifitas keluar rumah, kegiatan sekolah dirumahkan, bekerja dari rumah (work from home), bahkan kegiatan peribadahan pun di rumahkan. Dengan adanya wabah Covid-19 yang tengah merebak di berbagai negara khususnya di Indonesia yang tidak dapat diselesaikan hanya mengandalkan kebijakan pemerintah. Diperlukan kerjasama yang solid antara pemerintah, masyarakat, lembaga pengelola dana ZIS dalam memanfaatkan ZISWAF dengan maksimal agar memberikan kontribusi dalam penanganan dampak Covid-19.

Pembicaraan tentang zakat tidak dapat dilepaskan dari pembicaraan tentang konsep harta menurut Al-Qur'an, terutama tentang konsep kepemilikan yang akan meringankan si pemilik harta untuk mengeluarkan sebagian hartanya sesuai dengan ketentuan pemilik hakiki yaitu Allah Subhanahu Wa Ta'ala. Kemudian Allah mengizinkan manusia untuk menguasai harta tersebut dengan cara-cara yang telah ditetapkan.

Di masa pandemi seperti ini lembaga-lembaga amil zakat dituntut untuk dapat berkontribusi dalam penanganan masalah ekonomi yang diakibatkan oleh pandemi Covid-19. Zakat memegang peranan yang sangat penting dalam membantu kesejahteraan ummat, hal tersebut dapat dilihat bahwa Zakat merupakan Ibadah yang memiliki posisi penting, strategis, dan menentukan baik dari sisi ajaran maupun dari sisi pembangunan kesejahteraan umat. Dengan kata lain, selain Zakat dapat membersihkan jiwa dan harta benda, Zakat juga merupakan instrumen yang ampuh dalam menopang peningkatan ekonomi (Puskas BAZNAS, 2021).

Organisasi yang fokus dalam pengelolaan Zakat, Infak dan Sedekah tersebut sesuai dengan disahkannya UU Pengelolaan Zakat, No. 23 Tahun 2011 yang menggantikan UU No. 38 Tahun 1999, bahwa Organisasi Pengelola Zakat (OPZ) berbentuk Badan Amil Zakat (BAZ) dan Lembaga Amil Zakat (LAZ). Badan Amil Zakat merupakan organisasi pengelola zakat yang dibentuk langsung oleh pemerintah, sedangkan Lembaga Amil Zakat (LAZ) merupakan organisasi pengelola zakat yang 
dibentuk oleh masyarakat berfungsi melakukan pengumpulan, pengelolaan, serta pendistribusian (UU No. 23, 2011). Badan Amil Zakat Nasional (BAZNAS) menyebutkan bahwa potensi Zakat di Indonesia mencapai Rp 327,6 triliun per tahun yang bersumber dari zakat pertanian 19,79 triliun, zakat peternakan 9,51 triliun, zakat uang 58,76 triliun, zakat penghasilan dan jasa 139,07 triliun, dan zakat perusahaan 144,5 triliun (Puskas BAZNAS, 2021).

Mengingat besarnya dampak pandemi bagi masyarakat dan besarnya potensi zakat di Indonesia maka kajian mengenai variabel zakat sangat menarik untuk dilakukan. Penelitian ini dilakukan dengan tujuan untuk mengkaji urgensi dari adanya zakat, infak, dan sedekah (ZIS) bagi masyarakat di tengah masa Pendemi yang ditinjau berdasarkan prespektif Maqasid Syariah.

\section{LITERATURE REVIEW}

Dalam jurnal berjudul "Peran Distribusi Harta (Zakat) Sebagai Solusi Ekonomi Disaat Pandemi Covid-19 Pada Baznas Kabupaten Kepulauan Meranti" penulis Nur Sakinah, Menjelaskan bahwa pendistribusian harta yakni dana zakat pada BAZNAS Kabupaten Kepulauan Meranti untuk penanganan Covid-19 sudah tepat sesuai dengan syariah. Dimana dana zakat yang disalurkan pada masa pandemi Covid19 ini membuat para penerima manfaat menjadi tertolong. Dan dana zakat yang diberikan sangat besar manfaatnya dan membawa kemaslahatan bagi korban yang terkena dampak dari pandemi Covid-19 (Sakinah \& Maulana, 2021).

$$
\text { Dalam Jurnal berjudul }
$$

"Pembangunan Ekonomi Dalam Tujuan Maqasid Syariah" yang ditulis oleh Ali Rama dan Makhlan menjelaskan mengenai pembangunan ekonomi yang seharusnya diterapkan di dunia Muslim harus berbasis pada maqâshid syari'ah yaitu terciptanya keadilan distributisi melalui terpenuhinya seluruh kebutuhan dasar manusia agar dapat menjaga kemaslahatan kehidupan manusia. Pembangunan ekonomi menjadikan manusia sebagai pelaku dan objek utama dari pembangunan itu sendiri seiring fungsinya sebagai khalîfah di muka bumi (Rama \& Makhlan, 2013).

Dalam jurnal yang berjudul "Implementasi Operasional Zakat, Infak, dan Sedekah dalam mewujudkan Kesejahteraan Prespetif Ekonomi Islam" yang ditulis oleh Ulfah Alfiyah Darajat, dkk. menjelaskan mengenai penyaluran ZIS demi membantu kesejahteraan masyarakat yang mebutuhkan. Namun permasalahan dalam jurnal tersebut membahas mengenai implementasi ZIS, sedangkan dalam penelitian ini membahas mengenai urgensi ZIS di masa pendemi Covid-19 (Darajat, Suharto, \& Bahrudin, 2021).

Dalam jurnal yang berjudul "Analisis Maqasid Al-Syariah dalam Sistem Ekonomi Islam dan Pancasila" yang ditulis oleh Ubbadul Adzkiya yang didalamnya menjelaskan mengenai Konsep Maqasid Syariah dalam Ekonomi islam, serta implementasinya dalam perekonomian syariah. Sedangkan dalam penelitian penulis lebih membahas mengenai pandangan prespektif Maqasid syariah terhadap Urgensi ZIS di masa pendemi Covid-19 seperti sekarang ini (Adzkiya, 2020).

Dari empat literatur di atas belum ada yang membahas secara khusus urgensi zakat, infak, dan sedekah di masa pendemi Covid-19 prespektif Maqasid Syariah. Oleh karena itu tulisan ini hadir untuk lebih memahami bagaimana urgensi zakat, infak, dan sedekah di masa pendemi Covid-19 Prespektif Maqasid Syariah. Hal inilah membedakan pembahasan penelitian ini dengan beberapa literatur yang telah dipaparkan sebelumnya.

\section{METODE PENELITIAN}

Tulisan ini merupakan penelitian lapangan (field research) dengan pendekatan deskriptif kualitatif. Data primer penelitian dikumpulkan melalui observasi lapangan dan wawancara kepada pimpinan BAZNAS 
Kota Cirebon. Referensi pendukung sebagai data sekunder diperoleh dari artikel jurnal, buku, al-Quran, peraturan perundangundangan, dan sumber lainnya. Penelitian ini mengkaji mengenai urgensi Zakat, Infak, dan Sedekah menurut perspektif Maqasid Syariah dan bagaimana upaya BAZNAS Kota Cirebon dalam menangani dampak pendemi terhadap ekonomi. Metode yang dipakai oleh penulis dalam menyusun karya ilmiah ini adalah kualitatif untuk memahami hal-hal yang berkaitan dengan tema penelitian.

\section{KONSEP DASAR}

\section{Zakat, Infak, dan Sedekah}

Secara literal, zakat berarti tambah (alziyâdah), tumbuh, subur, dan berkembang (al-nama'). Sedangkan secara harfiah, zakat berarti: bersih/suci (althahârah), berkah (albarkah), rapi, patut, dan damai atau (alshalâh). Secara istilah zakat adalah memberikan harta apabila telah mencapai nishab dan haul kepada orang yang berhak menerimanya (mustahik) dengan syarat tertentu (Suma, 2013). Senada dengan itu, zakat berarti kewajiban seorang muslim untuk mengeluarkan nilai bersih dari kekayaan yang tidak melebihi satu nisab, diberikan kepada mustahik dengan beberapa syarat yang telah ditentukan (Soemitra, 2015).

Zakat merupakan salah satu kegiatan ibadah dalam Islam. Zakat termasuk ke dalam rukun islam yang ke empat yang merupakan pondasi wajib bagi orang-orang yang beriman selain dari pada mengucapkan dua kalimat syahadat, melaksanakan sholat lima waktu, berpuasa pada bulan ramadhan dan naik haji bagi yang mampu (Busrah \& Damayanti, 2020). Zakat merupakan penyerahan atau penunaian hak yang wajib yang terdapat di dalam harta untuk diberikan kepada orang-orang yang berhak. Mengeluarkan zakat hukumnya wajib dan zakat termasuk rukun islam melengkapi syahadat, shalat, puasa dan haji. Hal ini jelas diterangkan sebagaimana Firman Allah Subhanahu Wa Ta'ala:

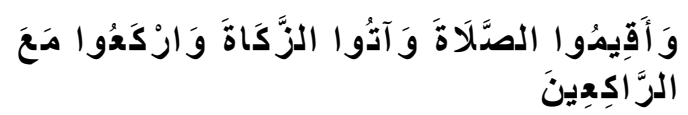

Artinya: Dan dirikanlah shalat, tunaikanlah zakat dan ruku'lah beserta orang-orang yang ruku (Q.S.Al Baqarah ayat 43).

Makna ayat tersebut menurut Tafsir al-Misbah adalah perintah menerima ajakan untuk beriman, lalu kerjakanlah salat dengan rukun yang benar dan berikanlah zakat kepada orang-orang yang berhak menerimanya. Salatlah berjamaah dengan orang-orang Muslim agar kalian mendapatkan pahala salat dan pahala jamaah. Hal ini menuntut untuk menjadi orang-orang Muslim (Shihab, 2011). Berdasarkan ayat tersebut jelaslah bahwa zakat adalah ibadah mahdhah yang sejajar dengan shalat. Dalam ayat lain Allah Subhanahu Wa Ta'ala berfirman:

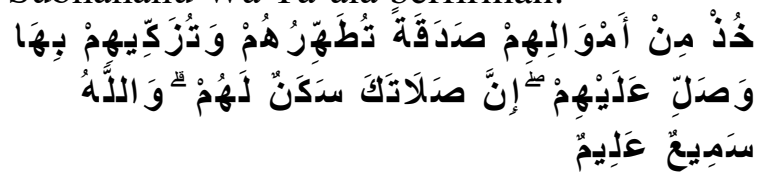

Artinya: Ambillah zakat dari sebagian harta mereka, dengan zakat itu kamu membersihkan dan mensucikan mereka dan mendoalah untuk mereka. Sesungguhnya doa kamu itu (menjadi) ketenteraman jiwa bagi mereka. Dan Allah Maha Mendengar lagi Maha Mengetahui (Q.S. at-Taubah ayat 103).

Maksud dari ayat tersebut adalah Rasulullah diperintahkan untuk mengambil sedekah dari harta orang-orang yang bertobat, yang dapat membersihkan mereka dari dosa dan kekikiran dan dapat mengangkat derajat mereka di sisi Allah. Doakanlah mereka dengan kebaikan dan hidayah, karena sesungguhnya doamu dapat menenangkan jiwa dan menenteramkan kalbu mereka. Allah Maha Mendengar doa dan Maha Mengetahui orang-orang yang ikhlas dalam bertobat (Shihab, 2011). Nabi diperintahkan untuk memungut zakat dari harta kekayaan orang-orang mukmin sebagai kewajiban ataupun sukarela. Bahkan Allah menerangkan ancaman bagi yang menentang adanya zakat.

Alokasi dana zakat merupakan terikat sehingga distribusinya hanya 
diberikan kepada delapan asnaf (golongan) sebagaimana Firman Allah Subhanahu Wa Ta'ala:

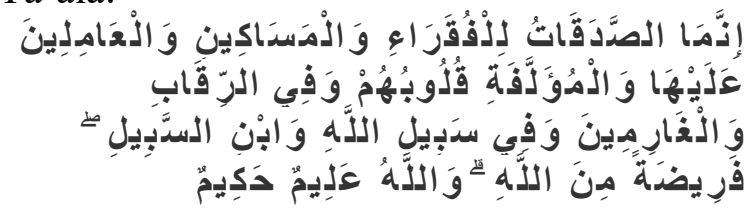

Artinya: Sesungguhnya zakat-zakat itu, hanyalah untuk orang-orang fakir, orang-orang miskin, pengurus-pengurus zakat, para mu'allaf yang dibujuk hatinya, untuk (memerdekakan) budak, orang-orang yang berhutang, untuk jalan Allah dan untuk mereka yuang sedang dalam perjalanan, sebagai suatu ketetapan yang diwajibkan Allah, dan Allah Maha Mengetahui lagi Maha Bijaksana (Q.S. at-Taubah ayat 60).

Zakat dapat didistribusikan kepada fakir, miskin, orang yang sedang berada dalam perjalanan. Selain itu, zakat dapat juga dimanfaatkan untuk pinjaman, atau untuk kepentingan sosial seperti membayarkan utang orang yang tidak mampu membayar. Pada masa awal sejarahnya, dalam masyarakat Islam sangat jarang ditemukan orang yang kelaparan dan mengemis untuk memenuhi kebutuhan hidupnnya. Karena begitu banyaknya zakat yang terkumpul, sampai-sampai amil zakat mengeluh tidak menemukan orang yang akan diberi zakat. Diriwayatkan, bahwa seorang amil zakat di wilayah Afrika mengeluh kepada Khalîfah 'Umar ibn 'Abd al-'Azîz karena dia tidak menemukan seorang fakir yang akan diberi zakat. 'Umar lalu berkata kepadanya, "Bayarkan utang orang-orang yang berutang." Amil zakat itu pun kemudian melaksanakan perintah itu, tetapi kemudian mengeluh lagi. 'Umar pun berkata, "Beli dan tebuslah budak, karena hal ini termasuk salah satu cara pembagian zakat." Sebenarnya, apabila zakat itu dikumpulkan kemudian dikeluarkan pada jalannya, maka akan terlihat dari penerapannya itu bahwa zakat adalah bentuk sistim takâful ijtimâ'iy yang paling agung (Shihab, 2011).

Selanjutnya yaitu infak, infak merupakan harta yang dikeluarkan oleh seseorang atau badan usaha di luar zakat untuk kemaslahatan umum (UU No. 23, 2011). Infak adalah mengeluarkan sebagian dari harta atau pendapatan atau penghasilan untuk suatu kepentingan yang diperintahkan ajaran Islam (Sabiq, 2015). Infak merupakan pemberian secara sukarela dengan niat karena Allah Subhanahu Wa Ta'ala tanpa mengharap balas jasa dari orang lain. Infak memiliki syarat harus ada benda / harta yang diserahkan, berbeda dengan sedekah secara umum yang bisa dilakukan dengan benda maupun nonbenda seperti ide dan tenaga.

Jika zakat ada nisabnya, infak tidak memiliki nisab. Infak dikeluarkan oleh setiap orang yang beriman, baik yang berpenghasilan tinggi maupun rendah, baik yang sedang lapang atau sempit.

Allah Subhanahu Wa Ta'ala menganjurkan seseorang yang mempunyai kelebihan harta untuk menginfakkan hartanya dijalan Allah, hal ini tercantum dalam Q.S.Al-Baqarah ayat 195, sebagai berikut:

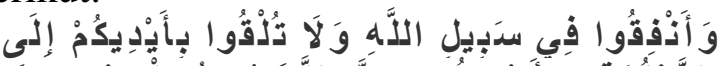

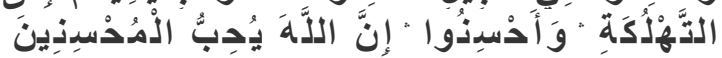

Artinya: Dan belanjakanlah (harta bendamu) di jalan Allah, dan janganlah kamu menjatuhkan dirimu sendiri ke dalam kebinasaan, dan berbuat baiklah, karena Sesungguhnya Allah menyukai orang-orang yang berbuat baik (Q.S. al-Baqarah: 195).

Allah Subhanahu Wa Ta'ala memerintahkan umat Islam untuk membelanjakan harta di jalan Allah sebagai bentuk ketaatan hamba. Manusia dilarang untuk menempatkan dirinya pada hal yang bisa membawa dampak buruk. Dengan berbuat baik maka manusia telah mengasihi orang lain dan dijanjikan pahala oleh Allah Subhanahu Wa Ta'ala.

Terakhir yaitu sedekah, kata sedekah itu berasal dari kata ash-shidq, yang berarti benar atau kebenaran. Adapun Sedekah menurut istilah merupakan pemberian suatu benda oleh seseorang kepada orang lain karena mengharapkan keridhaan dan pahala dari Allah Subhanahu Wa Ta'ala. Dan tidak mengharapkan suatu imbalan jasa atau 
penggantian (Uyun, 2015). Sedekah juga bermakna suatu pemberian yang diberikan oleh seorang muslim kepada orang lain secara spontan dan sukarela tanpa dibatasi waktu dan jumlah tertentu, suatu pemberian yang diberikan oleh seseorang sebagai suatu kebajikan yang mengharap ridha Allah Subhanahu Wa Ta'ala dan pahala semata (Amin, 2019).

Istilah sedekah yang intinya mengeluarkan harta dijalan Allah itu ada yang hukumnya wajib dan ada yang hukumnya sunah. Sedekah yang hukumnya wajib adalah seperti zakat, nazar, serta denda kafarat, contohnya seorang bernazar untuk sedekah atau menyembelih kurban. Kalau sudah dinazarkan dan apa yang menjadi doanya telah dikabulkan Allah Subhanahu Wa Ta'ala. tentu wajib dilaksanakan. Sedangkan sedekah yang hukumnya wajib itu seperti ketika seseorang memberikan hartanya kepada anak yatim atau untuk membangun mesjid, mengisi kotak amal, atau untuk pembangunan mushalla, pesantren, perpustakaan, atau memberi beasiswa. Sedekah yang hukumnya sunnah tidak ditetapkan besarannya. Seorang boleh menyedekahkan berapa saja dari hartanya, seikhlas dan sesukanya. Boleh lebih dari zakat, boleh juga kurang (Busrah \& Damayanti, 2020).

Islam menganjurkan pengikutnya untuk bersedekah dalam berbagai bentuk. Dalam al-qur"an dalam sejumlah ayatnya mengemukakan tentang besarnya pahala Sedekah, firman Allah Q.S. Al-Baqarah ayat 261 sebagai berikut:

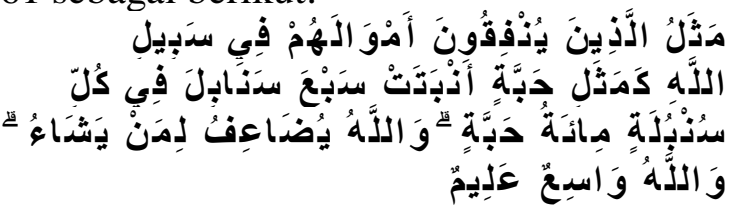

Artinya: Perumpamaan (nafkah yang dikeluarkan oleh) orang-orang yang menafkahkan hartanya di jalan Allah adalah serupa dengan sebutir benih yang menumbuhkan tujuh bulir, pada tiap-tiap bulir seratus biji. Allah melipat gandakan (ganjaran) bagi siapa yang Dia kehendaki. dan Allah Maha Luas (karunia-Nya) lagi
Maha mengetahui (Q.S.al-Baqarah ayat 261).

Orang yang mengeluarkan harta untuk ketaatan dan kebaikan akan memperoleh pahala berlipat ganda dari Allah. Perumpamaan keadaanya seperti orang yang menabur sebutir benih unggul di tanah. Dari benih tersebut tumbuh pohon kecil yang terdiri atas tujuh bulir. Pada tiaptiap bulir terdapat seratus biji. Inilah gambaran betapa banyaknya pahala berinfak yang diberikan Allah di dunia. Allah melipatgandakan pemberian-Nya untuk orang yang dikehendaki-Nya. Dia Maha luas karunia, Maha Mengetahui orang yang berhak dan yang tidak berhak (Shihab, 2011).

Zakat, infak dan sedekah memiliki perbedaan dalam waktu pembayaran. Waktu pembayaran zakat hanya bisa dilakukan pada saat tertentu saja seperti zakat fitrah selama bulan Ramadhan dan zakat maah dibayar ketika mancapai nisab dan haul. Sementara itu infak dan sedekah tidak memiliki ketentuan kapan harus dikeluarkan, artinya bebas untuk dilakukan kapan saja (Purwanti, 2020).

\section{Masa Pendemi Covid-19}

Pandemi Coronavirus Disease-19 (COVID19) merupakan wabah yang menyebar dari suatu wilayah ke banyak wilayah lainnya dengan cackupan negara dan mempengaruhi banyak penduduk dunia. Kaum muslimin di Indonesia sedang dilanda musibah besar yaitu menyebarnya virus corona (covid-19) sehingga banyak masyarakat yang terkena imbasnya. Dari segi ekonomi, masyarakat kecil terkena efek dari pembatasan sosial demi mencegah penyebaran virus ini. Sebagian harus terputus mata pencahariannya, terlebih lagi bagi yang sebelumnya memiliki kondisi ekonomi yang memprihatinkan.

Pada saat ini dunia berada dalam kondisi tatanan negara yang tidak teratur dan kacau dalam berbagai bidang kehidupan. Mengantisipasi dan mengurangi jumlah penderita virus corona di Indonesia 
pemerintah menetapkan kebijakan pembatasan aktifitas di luar rumah, kegiatan sekolah dirumahkan, bekerja dari rumah (work from home), bahkan kegiatan beribadah pun dirumahkan. Dampak pandemi tidak dapat diselesaikan hanya oleh pemerintah saja namun perlu kerjasama yang solid dari berbagai pihak seperti masyarakat dan lembaga pengelola dana ZIS dalam memanfaatkan ZISWAF dengan maksimal agar memberikan kontribusi dalam penanganan dampak Covid-19.

\section{Maqasid Syariah}

Konsep Maqașid Syari'ah bisa dipahami dengan merujuk ungkapan Imam alSyathibi, (w.790 H) melalui kitabnya AlMuwafaqat fi Ushul al-Syari'ah. Al-Syathibi mengatakan bahwa sesungguhnya syari'at itu ditetapkan tidak lain untuk kemaslahatan manusia di dunia dan di akhirat. Pada dasarnya syari'at itu dibuat untuk mewujudkan kebahagiaan individu dan jama'ah, memelihara aturan serta menyemarakkan dunia dengan segenap sarana yang akan menyampaikannya kepada jenjang-jenjang kesempurnaan, kebaikan, budaya, dan peradaban yang mulia, karena dakwah Islam merupakan rahmat bagi semua manusia (Al-Syathibi, 2005).

Maqașid Syari'ah dalam konteks ekonomi Islam merupakan jantung dalam ilmu ushul fiqh, karena itu Maqāṣid Syarī'ah menduduki posisi yang sangat penting dalam merumuskan ekonomi Islam menciptakan produk-produk perbankan dan keuangan syariah. Mempelajari ilmu ushul fiqh merupakan sesuatu yang sangat penting dan mutlak diperlukan, karena melalui ilmu inilah dapat diketahui kandungan dan maksud setiap dalil syara (al-Quran dan alHadits) sekaligus bagaimana menerapkan dalil-dalil syariah itu di lapangan. Lebih lanjut, al-Syathibi membagi tujuan syari'ah itu secara umum ke dalam dua kelompok, yaitu tujuan syari'at menurut perumusnya (syari') dan tujuan syari'at menurut pelakunya (mukallaf).
Maqasid al-syari'ah dalam konteks Maqasid al-syari' meliputi empat yaitu: 1) tujuan utama syariat adalah kemaslahatan manusia di dunia dan di akhirat; 2) syariat sebagai sesuatu yang harus dipahami; 3) syariat sebagai hukum taklifi yang harus dijalankan; dan tujuan syariat membawa manusia selalu di bawah naungan hukum. Untuk mewujudkan kemaslahatan bagi manusia di dunia dan akhirat, ada lima hal pokok yang harus dipelihara dan dijaga yaitu agama, jiwa, akal, keturunan dan harta.

Allah tidak mungkin menetapkan syari'at-Nya kecuali dengan tujuan untuk kemaslahatan hamba-Nya, baik di duniamaupun di akhirat kelak. Tujuan ini akan terwujud bila ada taklif hukum dan taklif hukum itu baru dapat dilaksanakan apabila sebelumnya dimengerti dan dipahami oleh manusia. Oleh karena itu semua tujuan akantercapai bila manusia dalam perilakunya sehari-hari selalu ada di jalur hukum dan tidak berbuat sesuatu menurut hawa nafsunya sendiri (Shidiq, 2021).

Para ulama ushul fiqh sepakat bahwa pengetahuan Maqasid syariah merupakan syarat utama dalam berijtihad guna menjawab berbagai persoalan ekonomi yang kian berkembang. Maqașid Syariah diperlukan untuk memformulasikan berbagai kebijakan mulai dari ekonomi makro, moneter, fiskal, keuangan publik hingga untuk menciptakan produk perbankan dan keuangan syariah. Maka infkorporasi wahyu perlu dilakukan dalam studi ilmiah sehingga pada sarjana Muslim tidak berorientasi pada pemikiran ekonomi konvensional.

\section{PEMBAHASAN DAN DISKUSI Profil BAZNAS Kota Cirebon}

Badan Amil Zakat Nasional (BAZNAS) merupakan badan resmi dan satu-satunya yang dibentuk oleh pemerintah berdasarkan Keputusan Presiden RI No 8 tahun 2001 yang memiliki tugas dan fungsi menghimpun dan menyalurkan zakat, infak dan sedekah (ZIS) pada tingkat nasional. 
Lahirnya Undang-Undang No 23 Tahun 2011 tentang pengelolaan zakat semakin mengukuhkan peran BAZNAS sebagai lembaga yang berwenang melakukan pengelolaan zakat secara nasional. Dalam UU tersebut BAZNAS dinyatakan sebagai lembaga pemerintah nonstruktural yang bersifat mandiri dan bertanggung jawab kepada Presiden melalui Menteri Agama (BAZNAS, 2021).

Badan Amil Zakat Nasional (BAZNAS) Kota Cirebon merupakan badan pengelola zakat yang didirikan berdasarkan atas Keputusan Direktur Jenderal Bimbingan Masyarakat Islam nomor DJ.II/568 Tahun 2014 sebagaimana telah disahkan pada tanggal 11 Februari 2015. Tentang pembentukan Badan Amil Zakat Nasional Kabupaten/Kota se-Indonesia pada tanggal 5 Juni 2014. BAZNAS Kota Cirebon berkedudukan di Jl Kanggraksan No 57 RT 05 RW 02 Kelurahan Harjamukti (BAZNAS Kota Cirebon, 2021b).

Kota Cirebon merupakan kota yang terletak di bagian timur Provinsi Jawa Barat dan berada pada jalur utama lintas pantura. Kota Cirebon memilki luas wilayah administrasi sekitar $37,358 \mathrm{~km}^{2}$ atau sekitar 3.736 hektar yang terbagi ke dalam lima kecamatan, yaitu Harjamukti, Lemahwungkuk, Pekalipan, Kejaksan dan Kesambi. Harjamukti memiliki luas wilayah yang paling besar mencapai 47,15\%, sementara Pekalipan paling kecil hanya mencapai $4,18 \%$. Jumlah penduduk Kota Cirebon dalam 5 (lima) tahun terakhir terus mengalami peningkatan dari sisi kuantitas. Pada tahun 2017, penduduk kota Cirebon berjumlah 313.325 jiwa yang lebih didominasi oleh kelompok umur produktif (15-64 tahun), yaitu sebanyak 215.237 orang atau 69,32 persen dan kelompok umur yang tergolong tidak produktif sebanyak 95.249 orang atau 30,68 persen (Pemkot Cirebon, 2021).

Di Indonesia, pengelolaan zakat itu telah diatur di dalam Undang-undang No 38 tahun 1999 tentang pengelolaan zakat kemudian digantikan oleh UU No 23 tahun
2011 dengan nama yang sama. Dalam UU tersebut mengatakan bahwa pengelolaan zakat dapat dilakukan oleh Badan Amil Zakat Nasional (BAZNAS), BAZNAS Provinsi dan BAZNAS Kota/Kabupaten, Lembaga Amil Zakat (LAZ) serta Unit Pengelola Zakat (UPZ). Zakat menurut UU No 23 tahun 2011 tentang pengelolaan zakat adalah harta yang wajib dikeluarkan oleh seorang Muslim atau badan usaha untuk diberikan kepada yang berhak menerimanya sesuai dengan syari'at Islam (UU No. 23, 2011).

Visi dan Misi BAZNAS Kota Cirebon, Visi BAZNAS Kota Cirebon yaitu "Menjadi Pengelola zakat terbaik dan terpercaya di Kota Cirebon". Lalu Misi BAZNAS terbagi menjadi Misi Umum dan Misi Khusus. Misi Umum BAZNAS diantaranya: Mengkoordinasikan BAZNAS Kota Cirebon dan LAZ dalam mencapai target-target Nasional, Mengoptimalkan secara terukur penghimpunan zakat se-Kota Cirebon, Mengoptimalkan pendistribusian dan pendayagunaan zakat untuk mengurangi angka kemiskinan, peningkatan kesejahteraan masyarakat dan permoderatan kesenjangan sosial, Menerapkan sistem manajemen keuangan yang transparan dan akuntabel berbasis teknologi informasi dan komunikasi terkini, Menerapkan sistem pelayanan prima kepada seluruh pemangku kepentingan zakat, Menggerakan dakwah islam dan mengkonsolidasikan seluruh elemen ummat Islam untuk kebangkitan zakat, Terlibat aktif dalam memimpin gerakan sadar zakat ditingkat Kota Cirebon yang berdampak secara nasional, Mengharus utamakan zakat sebagai instrumen pembangunan daerah menuju masyarakat yang adil, makmur sejahtera dan ta'at beragama, dan Mengembangkan potensi amil zakat yang unggul dan terpercaya serta menjadi rujukan di tingkat nasional.

Lalu Misi khusus BAZNAS Kota Cirebon diantaranya: Menjadikan BAZNAS Kota Cirebon sebagai sarana untuk mengaktualisasikan diri menjadi muslim 
yang mukhlis dan dan muhsin, Menjadikan BAZNAS Kota Cirebon sebagai sarana untuk mengaktualisasikan diri menjadi muslim yang berkarakter nafi'un lighairihi (memberi manfaat untuk sesama), Memfasilitasi kaum muslimin dan diri sendiri dalam membersihkan harta dan mensucikan jiwa, Menjadikan BAZNAS Kota Cirebon sebagai media ibadah dan amal sholeh untuk bekal mencapai ridho Allah dan bertemu Allah, dan Menjadikan BAZNAS Kota Cirebon sebagai media untuk memperkokoh ukhuwah islamiyah dan hubungan silaturrakhim.

Badan Amil Zakat Nasional (BAZNAS) Kota Cirebon merupakan badan pengelola zakat yang didirikan berdasarkan Keputusan Direktur Jenderal Bimbingan Masyarakat Islam Nomor DJ.II/568 Tahun 2014 tentang pembentukan Badan Amil Zakat Nasional Kabupaten/Kota SeIndonesia, tanggal 5 Juni 2014 sebagaimana telah diubah dengan Keputusan Direktur Jenderal Bimbingan Masyarakat Islam Nomor DJ.II/568 Tahun 2014 tentang Pembentukan Badan Amil Zakat Nasional Kabupaten/Kota Se-Indonesia, tanggal 11 Februari 2015. BAZNAS Kota Cirebon berkedudukan di Jl. Kanggraksan No.57 RT 05 RW 02 Kelurahan Harjamukti Kecamatan Harjamukti Kota Cirebon.

\section{Urgensi ZIS pada masa Pandemi Prespektif Maqasid Syariah}

Permasalahan ekonomi yang dihadapi masyarakat Indonesia akibat dampak pandemi dapat diselesaikan dengan beberapa solusi seperti: (1) penyaluran bantuan langsung tunai yang berasal dari zakat, infak dan sedekah; (2) penguatan wakaf baik berupa wakaf uang, wakaf produktif, waqf linked sukuk maupun wakaf untuk infrastruktur; (3) bantuan modal usaha untuk UMKM terdampak pandemi; (4) skema qardhul hasan; (5) peningkatan literasi ekonomi dan keuangan syariah; (6) melalui pengembangan teknologi finansial syariah (Hafizd, 2020; Iskandar, Possumah, \& Aqbar, 2020).
Operasional zakat infak dan sedekah dibagi menjadi dua, pada penghimpunan dana serta pendistribusiannya. Sumber dana pada penghimpunan dana zakat infak dan sedekah sebagaimana telah disebutkan dalam peraturan badan amil zakat nasional Republik Indonesia Nomor 5 Tahun 2018 tentang pengelolaan keuangan zakat bab tiga menjelaskan bahwa penerimaan dana dapat berasal dari zakat, infak, sedekah, dan dana sosial keagamaan lainnya (Darajat et al., 2021). Sumber dana utama yang digunakan dalam penghimpunan dana ZIS pada BAZNAS Kota Cirebon adalah berasal dari Zakat, Infak, dan Sedekah. Baik dari karyawan, anggota maupun donatur tidak tetap dan lainnya.

Adapun pendistribusian Zakat, Infak, dan Sedekah yang diterapkan di Indonesia terdapat dua macam kategori yaitu distribusi secara konsumtif dan produktif. Pertama, secara konsumtif bisa diartikan bahwa zakat infak dan sedekah langsung diberikan pada mustahik untuk memenuhi kebutuhan hidup. Hal tersebut dapat dilakukan dalam bentuk beberapa program yang telah ditentukan oleh lembaga amil zakat yang bersangkutan di antaranya, misalnya melalui program jum'at berbagi, petik pahala, dan lainnya. Pendistribusiannya dengan membagikan sembako atau makanan. Kemudian juga melalui program sosial bencana yang pedistribusiannya dilakukan ketika terjadi bencana pada suatu daerah. Kemudian selanjutnya dapat pula melalui program peduli kesehataan yang pendistribusiannya dengan memberikan fasilitas kesehatan sesuai dengan kebutuhan dan ketentuan mustahik yang telah ditentukan, misalnya ambulans gratis dan lain sebagainya. Kedua, secara tidak langsung Zakat, Infak, dan Sedekah didistribusikan secara produktif artinya bahwa dana yang disalurkan oleh amil zakat tidak bisa dinikmati secara langsung hasilnya oleh para mustahik. Pendistribusian zakat infak dan sedekah secara produktif yang diberikan kepada mustahik bisa meningkatkan perekonomian dan mewujudkan kesejahteraan masyarakat 
seperti melalui bantuan modal usaha, dan lainnya.

Begitupun dimasa pendemi seperti sekarang ini, dimana hampir setahun lebih penyebaran pandemi Covid-19 menimpa Indonesia, virus ini bukan hanya merampas ribuan nyawa, namun juga merampas perekonomiannnegara dan masyarakat serta merampas kehidupan sosial. Seperti, para pekerja yang dipulangkan, hancurnya dunia UMKM, sehingga berpotensi naiknya tingkat kemiskinan. Masyarakat muslim diingatkan untuk selalu membantu sesama terlebih kepada kaum yang lemah (berdampak) melalui Zakat, Infak, dan Sedekah. terlebih, potensi ZIS di Indonesia selama ini sangat berpengaruh besar untuk pemerdayaan ekonomi masyarakat. Beberapa ahli hukum islam juga mengatakan bahwa dana ZIS bisa digunakan sebagai pengelolaan bencana musibah, seperti pada saat ini terjadi pandemi Covid19.

ZIS harus didistribusikan kepada pihak penerima yang dimana setara dengan ketentuan dalam Islam (UU No. 23, 2011). Pendistribusian zakat harus sesuai dengan kualitas, keadilan, serta dapat diperhatikan prinsip dalam pemerataan, kewilayahan. Situasi pandemi menyebabkan banyak masyarakat mengalami penurunan ekonomi dimana pendistribusian ZIS bisa membantu mengurangi dampak tersebut. Dampak yang diakibatkan membuat perekonomian masyarakat tidak stabil dan menyebabkan penambahan jumlah kemiskinan di Indonesia. Masyarakat terdampak pandemi dapat digolongkan kedalam asnaf atau orang yang berhak menerima zakat.

Berkaitan dengan pembahasan diatas konsep Maqasid Syariah merupakan koridor yang relevan sebagai dasar pengembangan sistem, praktik, bahkan produk ekonomi di masa pendemi ini. Tatanan maqașid syari'ah dinilai oleh mayoritas ulama sebagai jalan terang bagi perjalanan dan pelayan ekonomi syariah, karena didasarkan pada kemaslahatan dan kesejahteraan (Nasuka, 2017). Sehingga menurut analisis penulis urgensi adanya ZIS pada masa Pandemi Covid-19 sesuai dengan empat dari lima nilai Maqasid Syariah yaitu untuk menjaga agama, jiwa, akal, dan harta. Nilai kemanusiaan sejalan dengan ajaran Islam untuk saling tolong menolong, dengan terperiharanya harta / ekonomi masyarakat maka umat Islam bisa terhindar dari kelalain dalam beragama. Selain itu jiwa dan akal pikiran umat Islam bisa terjaga dengan terperiharanya kesehatan dan terpenuhinya kebutuhan untuk memperoleh nafkah atau penghasilan. Berbagai program yang disusun oleh BAZNAS Kota Cirebon sesuai dengan kebutuhan yang ada dan tidak bertentangan dengan hukum Islam dan hukum positif. Penyelenggaraan program BAZNAS sudah sesuai dengan tujuan dari ZIS sendiri yaitu mensucikan harta yang dengan menyalurkan kepada asnaf yang membutuhkan.

\section{Upaya BAZNAS Kota Cirebon dalam Menangani Dampak Pendemi}

Berdasarkan kajian kepustakaan yang dilakukan penulis, urgensi zakat, infak, dan Sedekah di masa pendemi Covid-19 di BAZNAS Kota Cirebon memiliki beberapa program yang bertujuan membantu masyarakat yang terdampak pendemi Covid-19 dengan berbagai jenis bantuan yang digolongkan jadi beberapa program. Program tersebut dibagi menjadi beberapa jenis baik yang bertujuan untuk membantu masyarakat yang terdampak dari segi perekonomian ataupun yang terjangkit virus itu sendiri yang dimana BAZNAS Kota Cirebon memberikan bantuan berupa bantuan kebutuhan sehari-hari selama pasien tersebut melakukan isolasi mandiri dan juga beberapa jenis bantuan lainnya.

Urgensi ZIS di masa pendemi Covid-19 di BAZNAS Kota Cirebon sendiri terimplementasikan dengan terlaksananya program BAZNAS MEMBUMI (Membantu Dampak Pandemi) dimana dalam berjalannya program ini BAZNAS Kota Cirebon berkomitmen penuh dengan pemerintah Kota Cirebon untuk memberikan 
semangat optimistis kepada masyarakat yang terdampak Covid-19 bahwa kita semua mampu menghadapi pandemi ini dengan sangat baik. Berdasarkan data yang tercatat pada Agustus 2021 Program BAZNAS MEMBUMI mengalirkan dana Zakat, Infak, dan Sedekah (ZIS) total sebesar Rp 320.190.500 untuk 2.142 mustahik (orang yang berhak). Penyaluran bantuan dengan total sebesar Rp 320.190 .500 dari Program BAZNAS MEMBUMI (Membantu Dampak Pandemi) tersebut telah terdistribusikan pada program diantaranya: (1) Cirebon Peduli dengan total sebesar Rp 227.390.000, (2) Cirebon Taqwa dengan total sebesar $\mathrm{Rp}$ 5.180.000, (3) Cirebon Cerdas dengan total sebesar Rp 68.450.500, dan (4) Cirebon Sehat dengan total sebesar Rp 19.170.000 (BAZNAS Kota Cirebon, 2021a).

Hal ini menjadi salah satu bukti bahwa urgensi Zakat, Infak, dan Sedekah (ZIS) yang muzaki tunaikan dan dihimpun di BAZNAS Kota Cirebon ini sangat bermanfaat bagi masyarakat yang membutuhkan terutama di masa pandemi Covid-19 ini. Melalui program BAZNAS MEMBUMI ini BAZNAS Kota Cirebon akan terus beraksi, memberikan semangat optimistis hadir untuk warga masyarakat Kota Cirebon yang terdampak Pendemi.

\section{KESIMPULAN}

Zakat, Infak, dan Sedekah (ZIS) pada masa Pandemi Covid-19 sesuai dengan empat dari lima nilai Maqasid Syariah yaitu untuk menjaga agama, jiwa, akal, dan harta. Nilai kemanusiaan sejalan dengan ajaran Islam untuk saling tolong menolong, dengan terperiharanya harta / ekonomi masyarakat maka umat Islam bisa terhindar dari kelalain dalam beragama. Selain itu jiwa dan akal pikiran umat Islam bisa terjaga dengan terperiharanya kesehatan dan terpenuhinya kebutuhan untuk memperoleh nafkah atau penghasilan. Berbagai program yang disusun oleh BAZNAS Kota Cirebon sesuai dengan kebutuhan yang ada dan tidak bertentangan dengan hukum Islam dan hukum positif. Penyelenggaraan program
BAZNAS juga sudah sesuai dengan tujuan dari ZIS sendiri yaitu mensucikan harta yang dengan menyalurkan kepada asnaf yang membutuhkan. BAZNAS Kota Cirebon melaksanakan program MEMBUMI (Membantu Dampak Pandemi) dimana dalam berjalannya program ini BAZNAS Kota Cirebon berkomitmen penuh dengan pemerintah Kota Cirebon untuk memberikan semangat optimis kepada masyarakat yang terdampak Covid-19 untuk mampu menghadapi pandemi dengan baik.

\section{DAFTAR PUSTAKA}

Adzkiya, U. (2020). Analisis Maqashid AlSyariah Dalam Sistem Ekonomi Islam dan Pancasila. JESI (Jurnal Ekonomi Syariah Indonesia), 10(1), 23-35.

Al-Syathibi. (2005). Al-Muwafaqat Fi Ushul al-Syari'ah.

Amin, S. (2019). Optimalisasi Dana ZIS Pada LAZIS NU Kecamatan Ampel Kabupaten Boyolali. Az Zarqa': Jurnal Hukum Bisnis Islam, 11(2).

BAZNAS. (2021). Profil BAZNAS. Retrieved September 4, 2021, from https:baznas.go.id/profil

BAZNAS Kota Cirebon. (2021a). Pendistribusian Baznas Membumi (Membantu Dampak Pandemi). Retrieved September 4, 2021, from https://baznas.cirebonkota.go.id/2021/0 1/1047/

BAZNAS Kota Cirebon. (2021b). Sejarah (BAZNAS Kota Cirebon). Retrieved September 4, 2021, from https://baznas.cirebonkota.go.id/sejarah/

Busrah, B., \& Damayanti, A. (2020). Strategi Pengumpulan Dan Penyaluran Dana Infak/Sedekah ASN Pada Badan Amil Zakat Nasional (BAZNAS) kab. Polewali Mandar. J-Alif: Jurnal Penelitian Hukum Ekonomi Syariah Dan Budaya Islam, 5(1), 1-12.

Darajat, U. A., Suharto, S., \& Bahrudin, M. (2021). Implementasi Operasional Zakat Infak Dan Sedekah Dalam Mewujudkan Kesejahteraan Perspektif Ekonomi Islam (Studi Di Koperasi 
Simpan Pinjam Pembiayaan Syariah Baitul Maal Wat Tamwil Fajar Metro). Ijtimaiyya: Jurnal Pengembangan Masyarakat Islam, 14(1), 55-90.

Hafizd, J. Z. (2020). Peran Bank Syariah Mandiri (Bsm) Bagi Perekonomian Indonesia Di Masa Pandemi Covid-19. Al-Mustashfa: Jurnal Penelitian Hukum Ekonomi Syariah, 5(2), 138. https://doi.org/10.24235/jm.v5i2.7402

Iskandar, A., Possumah, B. T., \& Aqbar, K. (2020). Peran Ekonomi dan Keuangan Sosial Islam saat Pandemi Covid-19. Jurnal Sosial \& Budaya Syar'i FSH UIN Syarif Hidayatullah Jakarta, 7(7), 625-638.

Nasuka, M. (2017). shid Syariah sebagai Dasar Pengembangan Sistem, Praktik, dan Produk Perbankan Syariah. DIKTUM: Jurnal Syariah Dan Hukum, 15(1), 1-10.

Pemkot Cirebon. (2021). Pemerintah Daerah Kota Cirebon. Retrieved from https://www.cirebonkota.go.id/

Purwanti, D. (2020). Pengaruh zakat, infak, dan sedekah terhadap pertumbuhan ekonomi Indonesia. Jurnal Ilmiah Ekonomi Islam, 6(1), 101-107.

Puskas BAZNAS. (2021). Outlook Zakat 2021. Retrieved from https://puskasbaznas.com/publications/ books/1418-outlook-zakat-indonesia2021
Rama, A., \& Makhlan, M. (2013). Pembangunan Ekonomi Dalam Tinjauan Maqashid Syari'ah. Dialog, 36(1), 31-46.

Sabiq, S. (2015). Fikih Sunnah-Jilid 2 (Vol. 5). Jakarta: Cakrawala Publishing.

Sakinah, N., \& Maulana, A. (2021). Peran Distribusi Harta (Zakat) Sebagai Solusi Ekonomi Disaat Pandemi Covid-19 Pada Baznas Kabupaten Kepulauan Meranti. Kutubkhanah, 20(1), 65-79.

Shidiq, G. (2021). Teori Maqashid alSyari'ah dalam Hukum Islam. Majalah Ilmiah Sultan Agung, 44(118), 117130.

Shihab, M. Q. (2011). Tafsir Al-Mishbah. Jakarta: Lentera Hati.

Soemitra, A. (2015). Bank dan LembagaKeuangan Syariah. Jakarta: Prenadamedia Group.

Suma, M. A. (2013). Zakat, Infak, dan Sedekah: Modal dan Model Ideal Pembangunan Ekonomi dan Keuangan Modern. Al-Iqtishad: Jurnal Ilmu Ekonomi Syariah, 5(2).

UU No. 23. Undang-Undang RI Nomor 23 tahun 2011 tentang Pengelolaan Zakat. , (2011).

Uyun, Q. (2015). Zakat, Infaq, Shadaqah, Dan Wakaf Sebagai Konfigurasi Filantropi Islam. Islamuna: Jurnal Studi Islam, 2(2), 218-234. 